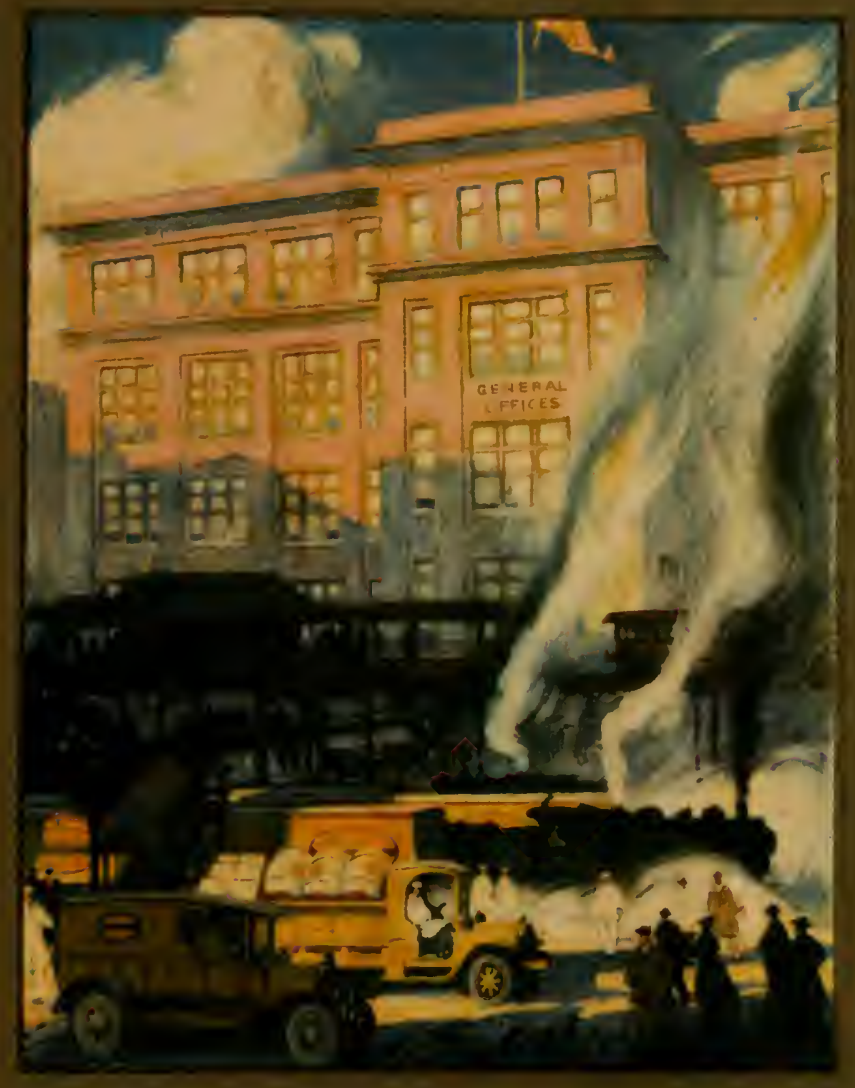

$$
\begin{aligned}
& \triangle R M A O U R \\
& \text { Avili? }
\end{aligned}
$$

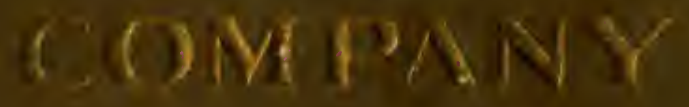

$$
\begin{aligned}
& +9+8
\end{aligned}
$$




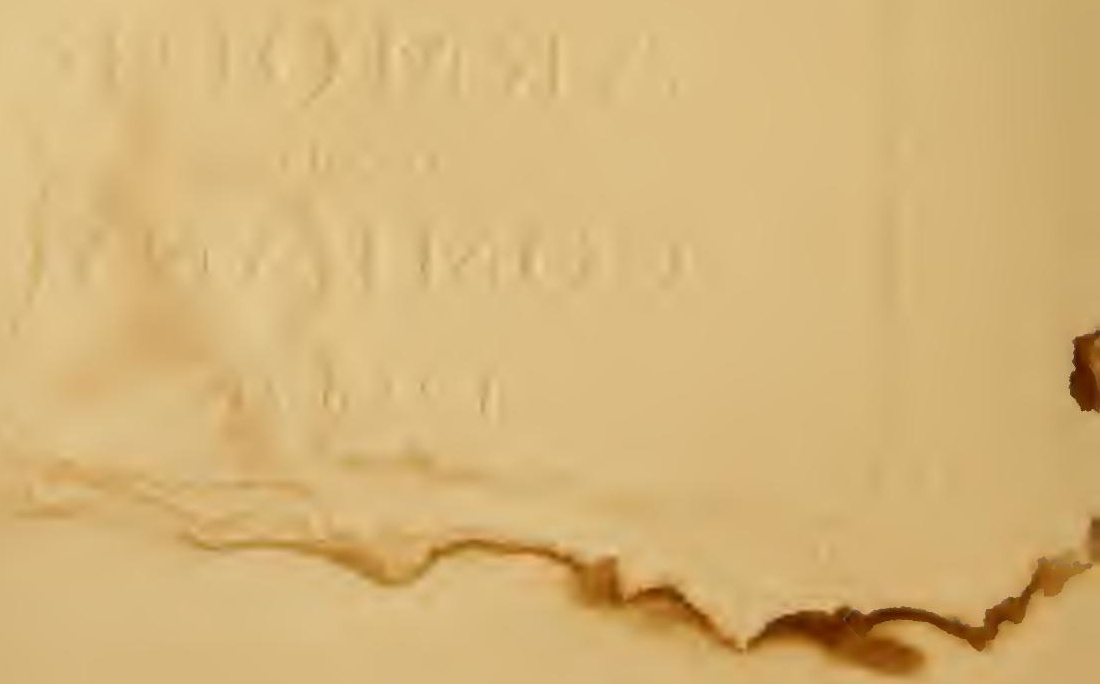





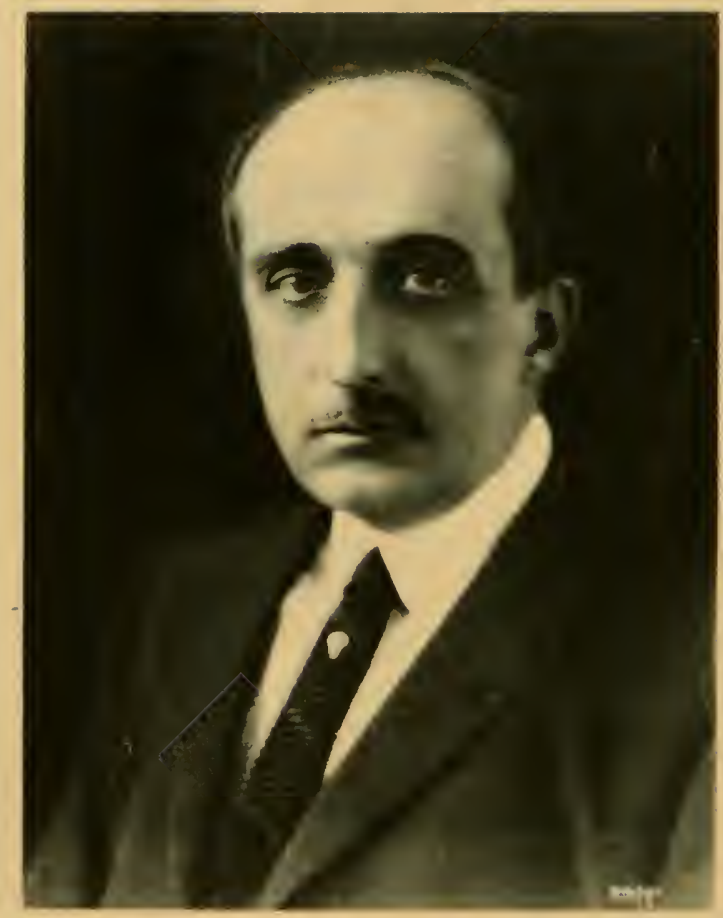

R. Oden Armous 


\section{ARMOUR AND}

COMPANY

\section{8}

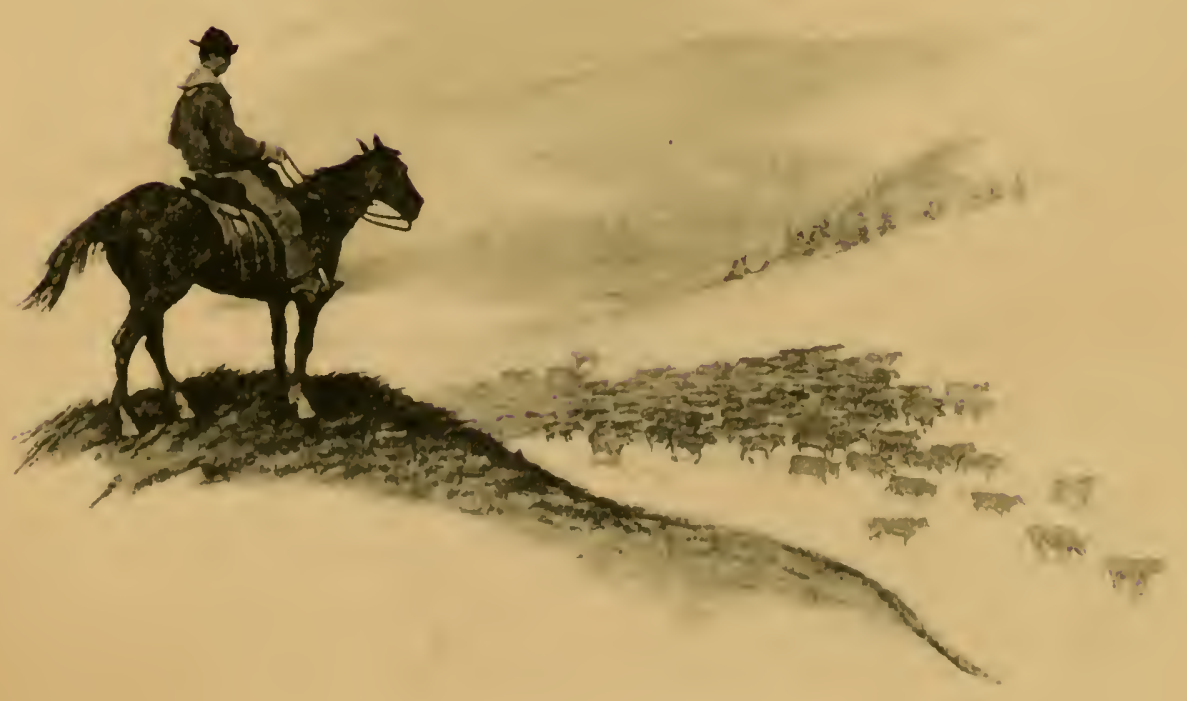




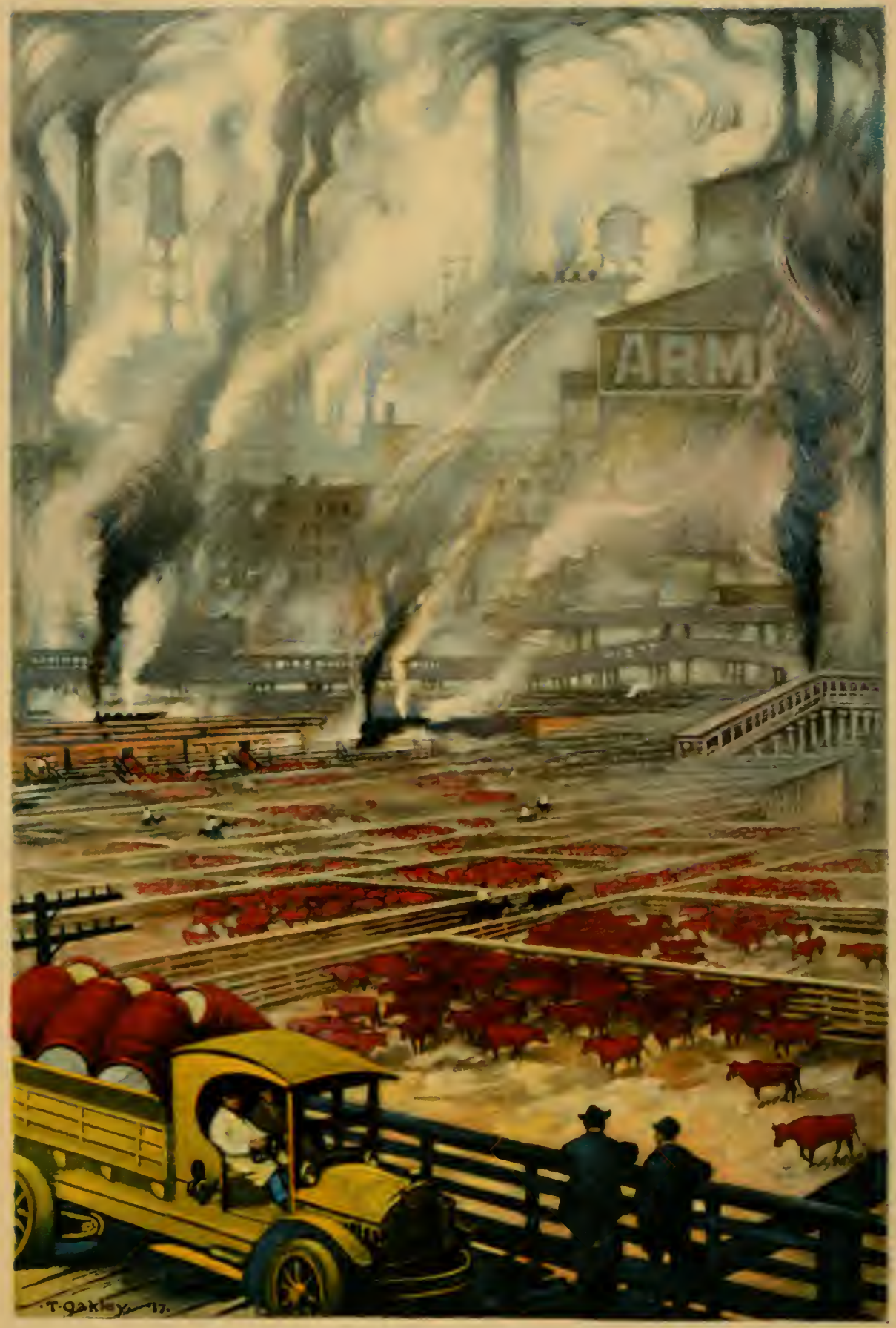




\section{THE ARMOUR IDEALS OF SERVICE}

BY J. OGDEN ARMOUR

T the conduct of a big industry which markets its output in small units through retailers to the public, two things are essential to L success - the good will of the people and profits. The two are interrelated. The first cannot obtain at the sacrifice of the second. Big business cannot exist without the consent of the people - and ought not to exist without their approval.

These are the ethics of modern commercialism, and the requirements must be met if a concern is to prosper and grow.

In a business as highly competitive as the preparation and purveying of foods, the finished article goes to the consumer for a sum nearer the actual cost of the raw material than does the completed product in almost any other line of human endeavor. To make a profit, therefore, the keynote of success in this industry must be volume. And volume can only come through a highly organized, comprehensive and expert service.

Our methods must be economically sound. They must be beneficial. I cannot emphasize this too strongly.

We must serve most efficiently both the producer who furnishes us the raw material and the consumer who buys the finished products. This is not philanthropy - it is good business sense. We employ nearly sixty thousand men; we have millions of dollars invested in packing plants, in branch distributing stations, in refrigerator cars, tank cars, ocean freighters. If these are allowed to lie idle, they do so at a great loss.

Thus it has become necessary to our own existence to impose upon ourselves far greater tasks than any outsider could set for us, to intensify our efficiency, to effect most salient economies, to develop our skill in the highest degree. From the inception of our business our progress has been measured by these motives.

Today, when war requirements strain all facilities to the utmost and co-ordination is more important than ever before, I am glad to know that in the upbuilding of our organization to its present point of efficiency, and in thus serving ourselves, we have likewise found it possible to better serve the nation in its time of need. 


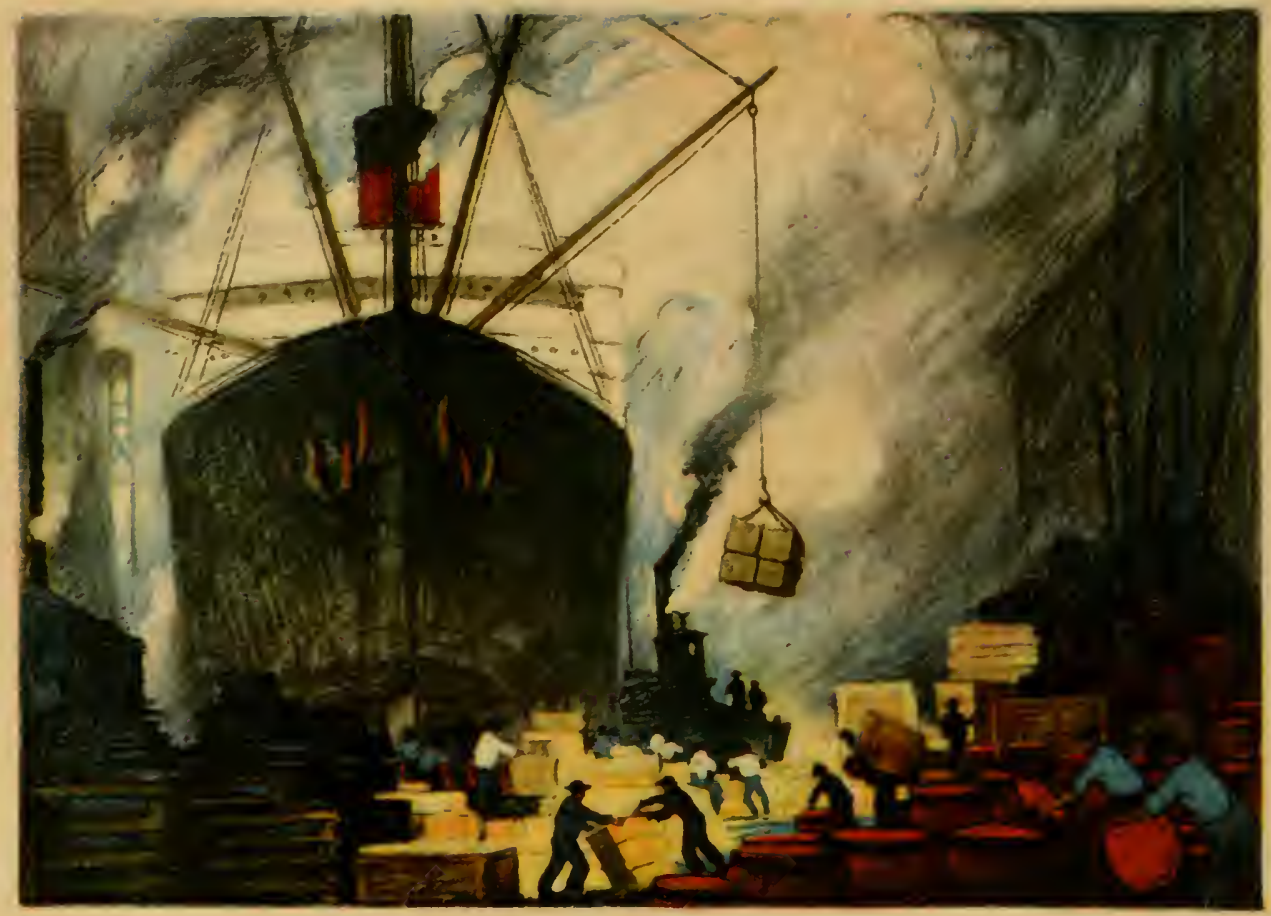

\section{ARMOUR AND COMPANY IN WAR-TIME}

PERATING in times of peace on a basis of highly organized efficiency, in the crisis of war the Armour organization found it easy to rise to an emergency-they were already prepared for it. Buying in scores of different markets, manufacturing in scores of different plants, operating thousands of refrigerator cars traversing the whole country, and with a mobile, highly developed organization, the Armour system has made it possible to move normal supplies in the normal way. The problem was simply one of easily effected readjustment and rerouting. So that despite the fact that it became necessary to divert one-seventh of the country's meat supply for shipment to our own and our Allies' armies abroad, and for the feeding of faminestricken war-sufferers, the usual Armour volume was handled without confusion or delay.

Likewise this same unified system has made it possible to meet the new problems created by the needs of provisioning army cantonments. As an instance, it was formerly the practice of army purchasing agents 
to buy supplies at a central point and supervise transportation to destination. Today, an order is simply issued to Armour and Company, and the Armour distributing machinery delivers with dispatch wherever supplies are needed.

Armour and Company were among the first to place their plants, equipment and personnel at the disposal of the Government. Accepting this willingness to co-operate, the Government has drawn freely upon the Armour resources, and today hundreds of Armour men are serving as volunteers in many capacities - from highly trained executives down to laborers experienced in handling perishables in refrigerator service.

Similarly, production has been crowded to the utmost. Two new packing houses and an addition to a third, the construction of an enormous oleomargarine plant, four new milk condensories, enlarged facilities for handling fish, eggs, cheese, poultry, canned fruits, vegetables - all of these aid in the conservation and organization of the national food supply. The Armour Domestic Science Department is showing hundreds of thousands of housewives how to use foods most efficiently, without waste.

Visitors are excluded from all plants during the war.

A school for telegraphers is training men for Army signal service, and recruiting offices are established in the main plants. Among the employees the formation of an Armour Soldiers' and Sailors' Club provides for comfort and cheer to the 1500 Armour men with the colors, with benefit to the morale of both the soldiers and those at home. Armour and Company, realizing that the nation has staked its all in the world struggle, is stopping at nothing in aiding the Government in a successful prosecution of the war.

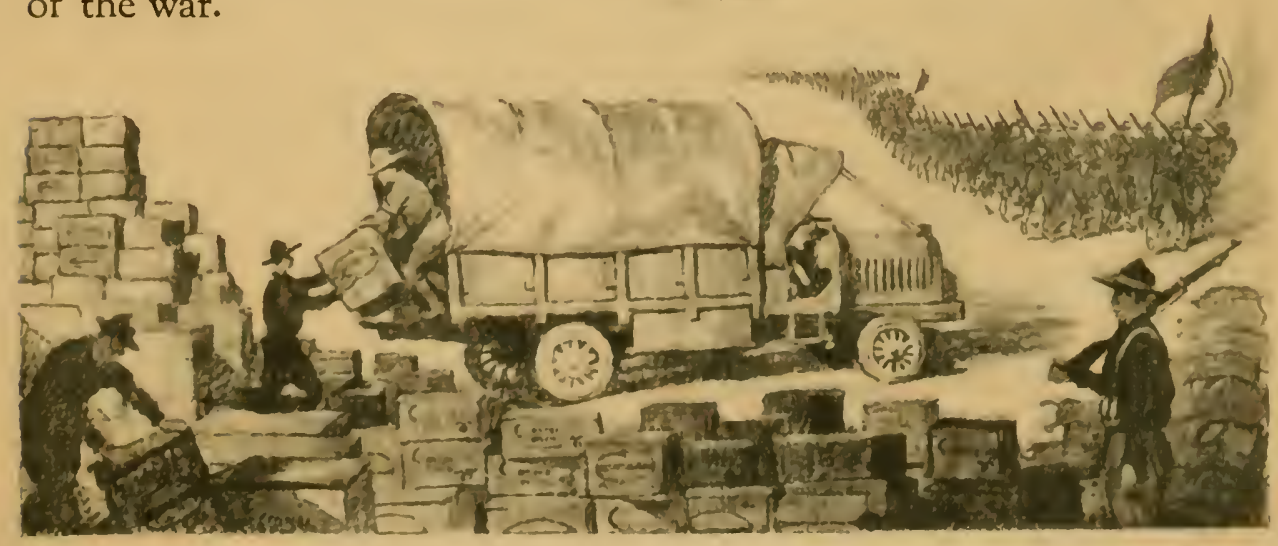




\section{ARMOUR'S ORGANIZATION UTILIZED TO CAPACITY}

^ FROM MEAT PACKERS - TO FOOD PURVEYORS

THE selling of such commodities as canned fruits and vegetables, eggs, fish, rice, coffee, grape juice and other

1 non-meat foods has come about as a necessary evolution in the Armour business, necessary to the full utilization of the organization required for the handling of meats, and hence for the most economic operation.

If, on the one hand, the supply of livestock were regular and certain, and on the other the market for meats presented a stabilized and unlimited outlet, the various departments of the Armour institution could devote themselves to the selling of purely packing-house products without end. But shortages in livestock, irregular receipts and shifting markets make this impossible. To the economic maintenance of the vast distributing system necessary for furnishing meats, with its thousands of refrigerator cars, branch-houses equipped with coolers, and an extensive force of salesmen, it has become necessary from time to time to develop and add new W 3 lines, thus spreading the overhead charges over

This has resulted in greatly increasing volume and lowering operating expenses per hundredweight,

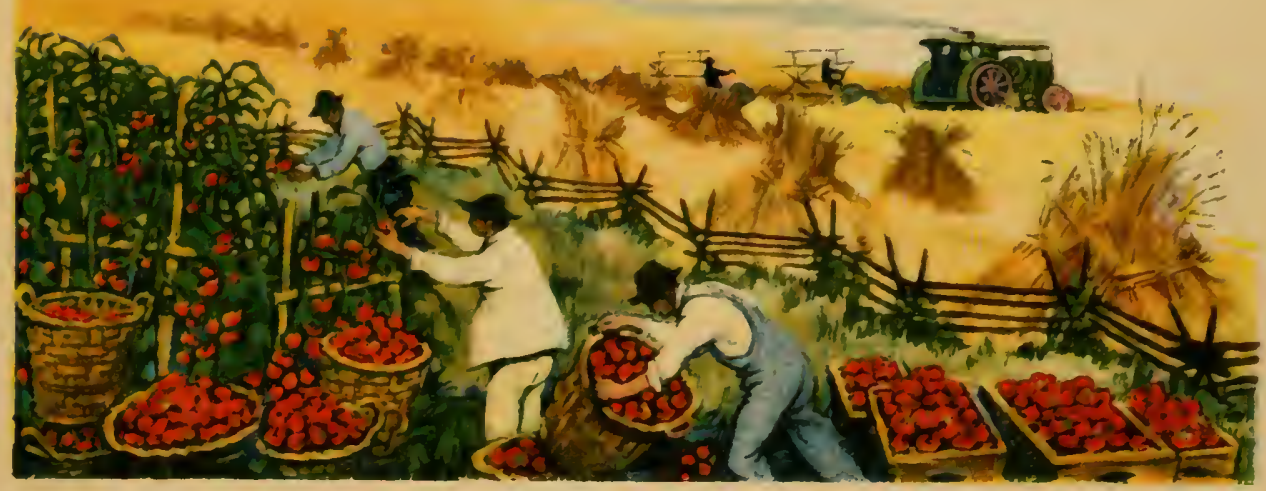


which in turn proportionately lowered prices to consumers for the same quality, or added value at the established price.

Naturally, the first additions to the line were those most closely related to meats; and as the demand for these grew, new products were added which, while seemingly having no direct connection with meats, were sold by the same retailers who handled meats and thus logically became selling opportunities for Armour salesmen. Being able to buy a larger part of his necessities in one transaction, the merchant welcomes this plan. His order is sent in one shipment and under one invoice. Time and expense are saved in buying, bookkeeping, checking separate bills and shipments, and in selling. Under the Oval Label Armour has standardized many foods formerly little used, so that today the consumer can select with the fullest assurance of recognized value an unvarying quality backed by an immense investment.

Selecting at the source of production, Armour can choose the highestgrade products of the country's farms, fisheries and orchards, prepare and pack them under closest supervision, and market them most economically.

It would be as impossible to perform the present-dayArmour service built on the lines of the old pioneer meat-packing inaustry as it would be to carry on modern transportation by old stage-coach methods.

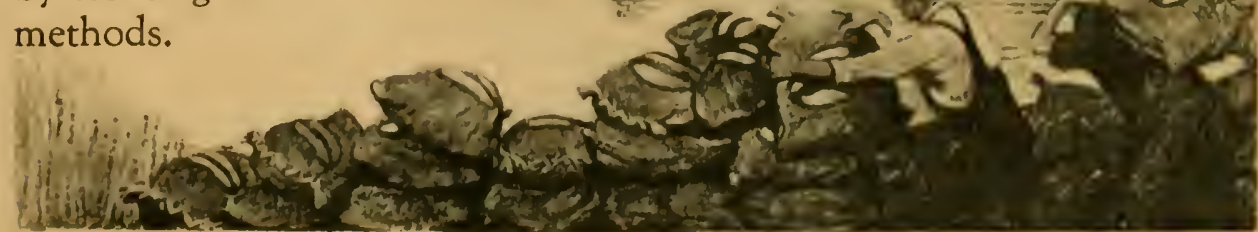




\section{THE LIVESTOCK AND MEAT SITUATION}

ORE and more, as the war progresses, do the greater production of livestock and the conservation of meat become pressing 12 necessities.

While there has been a numerical increase of livestock in the United States in 1917, the tendency of farmers to ship their cattle and hogs before they are properly finished, due to advanced cost of feed and eagetness to get high market prices, has brought about a decreased poundage per animal. Our own records, borne out by those of the industry in general, show a loss of weight of approximately ten per cent. in 1917 as compared with 1916. This offsets the increase in numbers. During 1917 Armour and Company paid to livestock producers in the United States alone, the sum of $\$ 341,743,275.97$ for cattle, hogs and sheep, or $\$ 109,167,133.05$ more than a similar poundage would have cost at the 1915 scale of prices. This additional sum necessarily had to be collected from consumers to be turned over to producers.

War conditions have created a tremendous demand. Herds of meat-producing animals in Europe have been diminished by approximately 114,000,000 head. Supplies from South America and Australia have been cut off by lack of ships. The mobilizing of over a million American soldiers has increased consumption tremendously.

War-time wages also lead to more active buying. In England, for example, the working-classes, who formerly ate meat only at weekly intervals, now eat it daily. To a considerable extent similar conditions in America have had a like effect.

All of these factors indicate that livestock and meat prices will undoubtedly remain high for a long time to come. So tremendous has the problem become that only concerted and simultaneous action by producer, purveyor and consumer can bring relief. The task is staggering in its immensity, but there are many hopeful indications.

Obviously, we must look first to the producer. For him the Government has largely taken the speculation out of production, and inasmuch as his gains are assured for years to come he can combine patriotism with profit by increasing and improving his herds. He must breed for quality that will produce maximum weight in the shortest 
time. Every unused nook and corner of his farm should grow feed for his animals. Surplus dairy calves should be fed no longer than is necessary to bring them to the veal stage, thus conserving feed, while beef calves should be saved and brought to earliest maturity.

The consumer's contribution lies in using as little meat as possible. The saving of one ounce of meat daily per person in the United States would be equivalent to an additional annual supply of over two million cattle. Meatless days, the more general use of fish, poultry and vegetables, guarding against waste-all will aid in relieving the situation.

In this crisis Armour and Company have a proper sense of their responsibility, and the whole machinery of the organization is geared up to meet it. Production is paramount, and today the wisdom of the Armour policy for years past, of consistent reinvestment of earnings in equipment and plant expansion, becomes amply evident. Because of this, markets are made doubly certain for the American producer, manufacturing is conducted with utmost facility and economy, and a neverfailing distributing outlet is provided for all that the farmer can raise.

While it is conceded that the packing industry is one of the most efficiently conducted industries in the world, in the Armour plants even more extreme war-time measures for food conservation are in effect. The crying need for fats is realized; it is being met. Primal cuts are carefully trimmed to save all fats which under less watchful methods would go into inedible grease. Small individual fat separators conserve other fats and keep them sweet and clean. Lean meats are trimmed and saved. Not an ounce of edible food that can be used is lost.

Through such methods as these, through the utilization of by-products to the point that fresh meat can be sold approximately at cost, through the factoring of other meat products at the lowest margin, Armour service is rendered at a cost that is marvelously low. Armour service is as inexpensive as it is efficient.

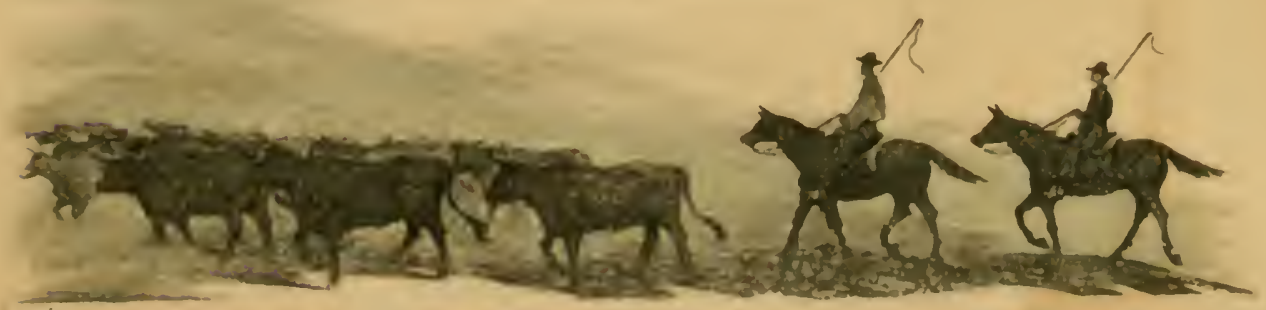




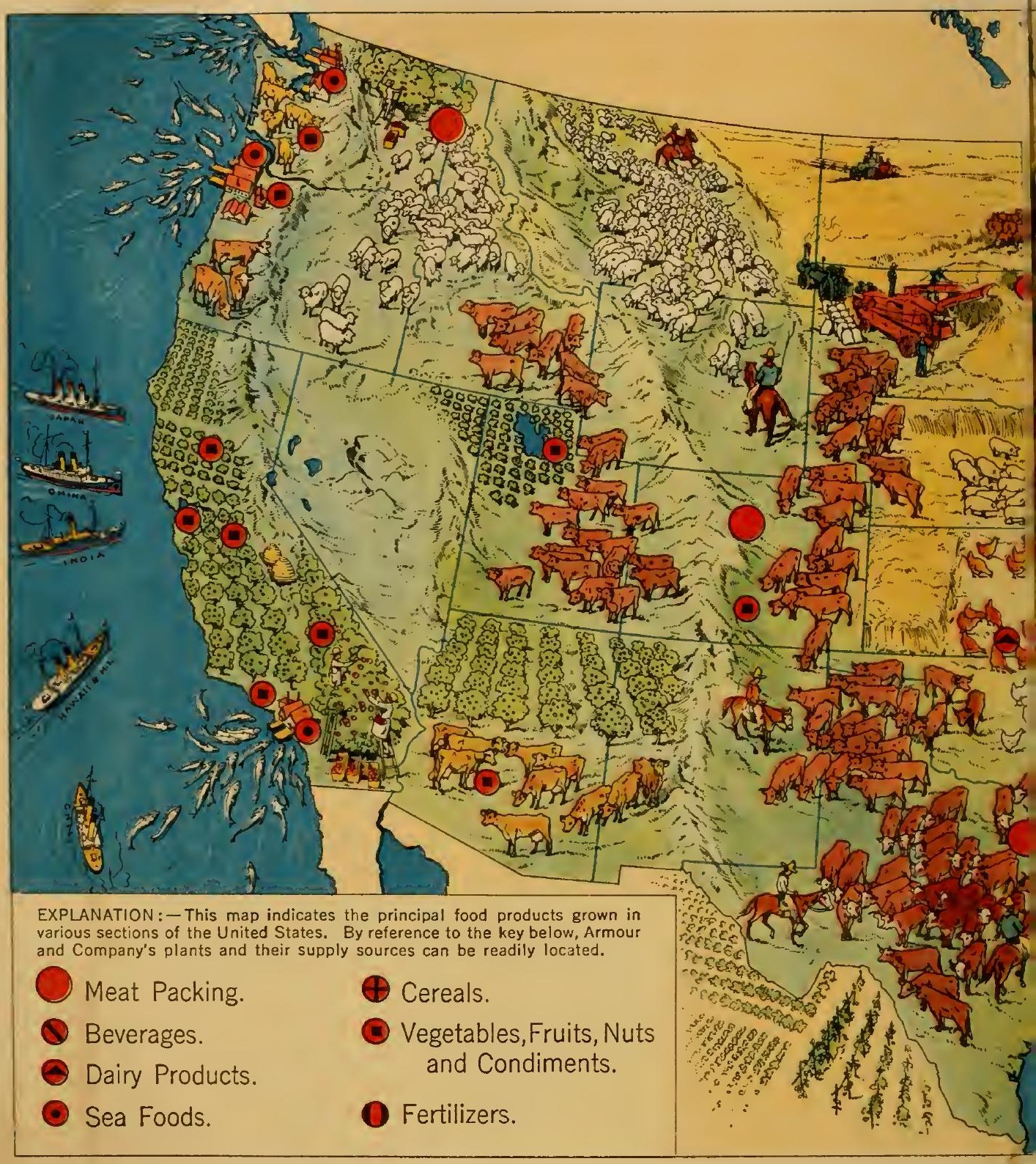

\section{ARMOUR'S SELECTION FROM THE}

Certain sections produce the choicest of foods, the most select in quality, the most abundant in quantity. In these regions are located the Armour plants and Armour buyers, situated to secure at the source the high-grade products that measure up to the Armour standard.

Meat-packing plants are located as near centers of production as economical operation, governed by labor conditions, accessible fuel and water, and adequate transportation facilities, will permit. Shortened freight hauls mean a 


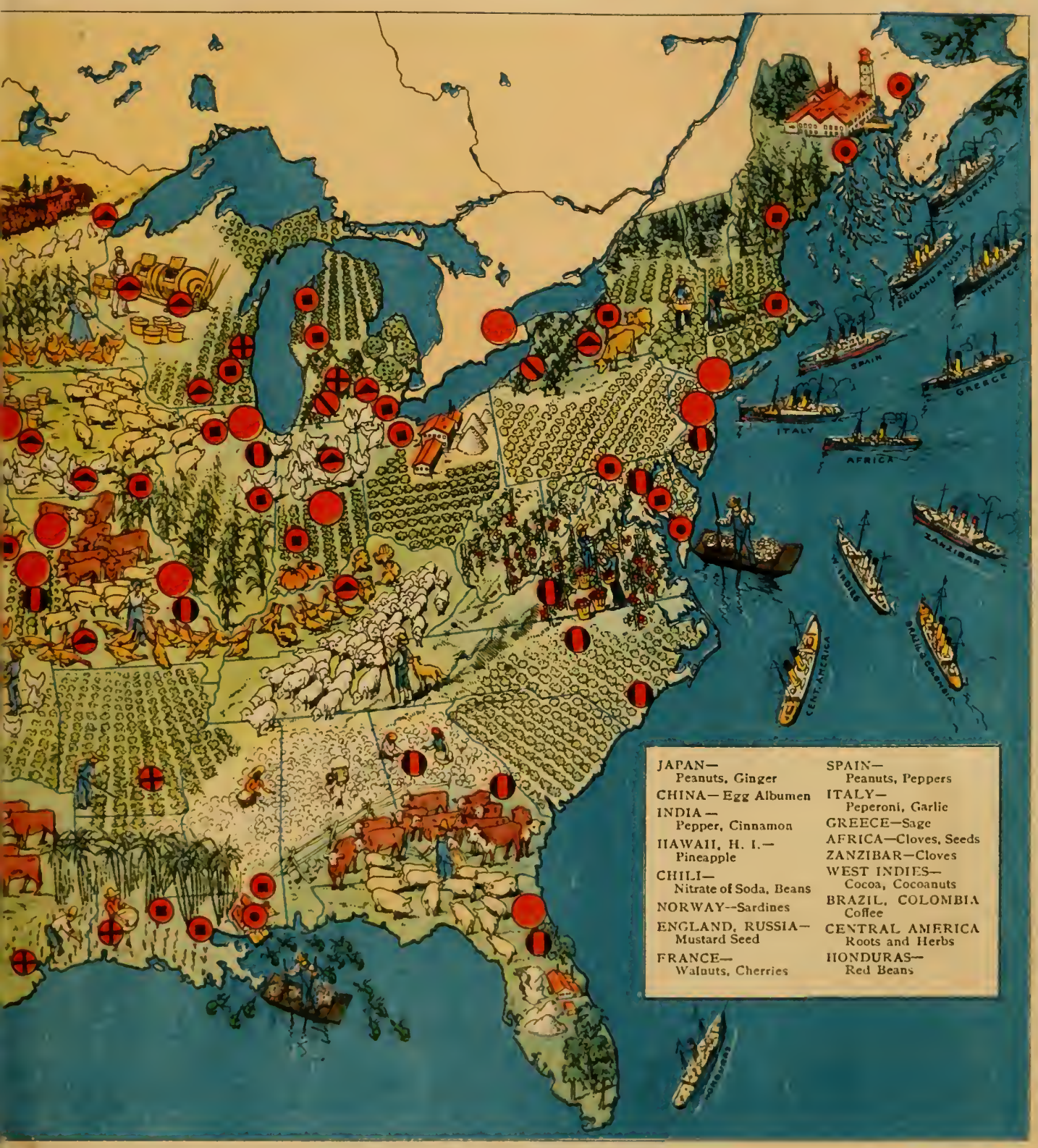

\section{BEST SOURCES OF FOOD SUPPLY}

saving to producers; for meat animals shrink in weight when it is necessary to ship them long distances; likewise consumers are relieved of paying freight charges on the inedible portions which constitute forty per cent. of the live animal. Inasmuch as over eighty per cent. of the livestock Armour and Company slaughter in Chicago and west of Chicago is consumed in the territory east of the Mississippi River, the vast saving this produces for the consumers is readily apparent. 



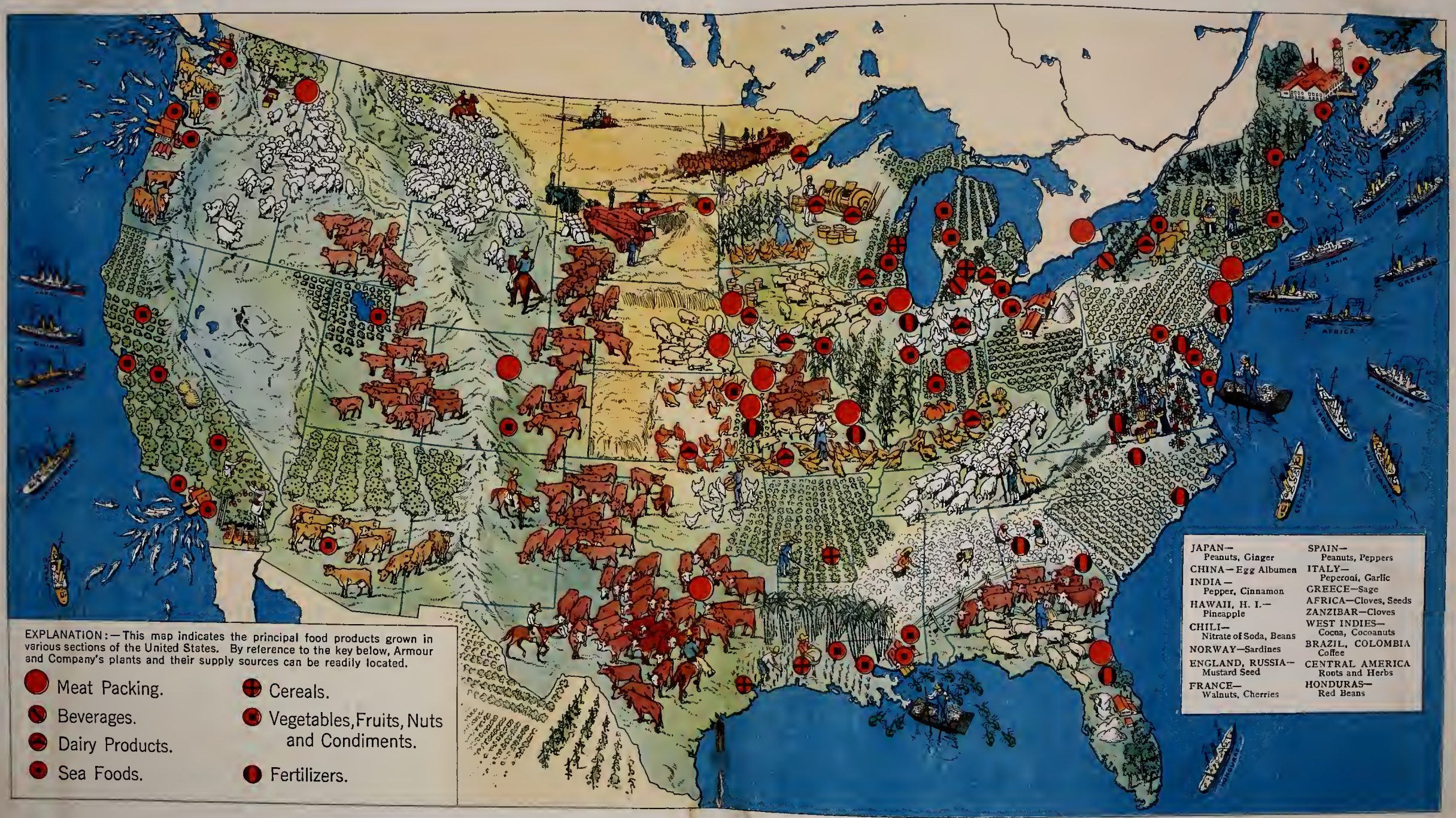

ARMOUR'S SELECTION FROM THE

Certain sections produce the choicest of foods, the most select in quality, the most abundant in quantity. In these regions are located the Armour plants and Armour buyers, situated to secure at the source the high-grade products that measure up to the Armour standard.

Meat-packing plants are located as near centers of production as economical operation, governed by labor conditions, accessible fuel and water, and adequate transportation facilities, will permit. Shortened freight hauls mean a

\section{BEST SOURCES OF FOOD SUPPLY}

saving to producers; for meat animals shrink in weight when it is necessary to ship them long distances; likewise consumers are relieved of paying freight charges on the inedible portions which constitute forty per cent. of the live animal. Inasmuch as over eighty per cent. of the livestock Armour and Company slaughter in Chicago and west of Chicago is consumed in the territory east of the Mississippi River, the vast saving this produces for the consumers is readily apparent. 


\title{
FINANCIAL STATEMENT
}

\author{
Fiscal Year Ending October 27, r917
}

\section{INCOME AND EXPENDITURES}

\section{INCOME}

On Manufacture and Sales, after deducting charges for Repairs, Depreciation, and Reserve for Income Tax

\section{EXPENDITURES}

Interest on Bonds

$\$ 21,501,562.87$
$208,000.00$

$\$ 30,628,155.86$

Interest on Borrowed

$\$ 2,240,422.27$

$3,509,055.34$

$2,072,549.61$

$1,512,565.77$

Taxes, Insurance, etc.

$208,000.00$

Less Contribution to Pension Fund

$21,293,562.87$

$\$ 30,628,155.86$

ASSETS AND LIABILITIES (OCTOBER 27, 1917)

CAPITAL ASSETS: ASSETS

Lands, Buildings, Plants, Machinery, etc. . . . . . . . . .

Refrigerator and Other Cars . . . . . .

Car Trust Agreement . . . . . . . . . . . . . .

Investments in Allied Companies. . . . . . . . .

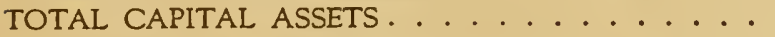

\section{CURRENT ASSETS:}

Inventories of Product, Material and Supplies ......

Miscellaneous Marketable Investments . . . . . . . .

Bills Receivable ................

Accounts Receivable.

Cash on Hand and in Banks

TOTAL CURRENT ASSETS

CURRENT LIAEILITIES:

Bills Payable

\section{LIABILITIES}

Accounts Payable . . . . . . . . . . .

TOTAL CURRENT LIABILITIES . . . . . . . .

RESERVES:

For Bond Interest

For Income Taxes

TOTAL RESERVE

CAPITAL LIABILITIES:

Bonds

Capital Stock . . . . . . . . . . . . .

Surplus .

NET CAPITAL INVESTMENT

ซ⿻

\section{OFFICERS}

J. OGDEN ARMOUR, President. CHAS. W. ARMOUR, Vice-President. GEO. B. ROBBINS, Vice-President. ARTHUR MEEKER, Vice-President. F. EDSON WHITE, Vice-President. ROBT. J. DUNHAM, Vice-President. E. A. VALENTINE, Vice-President. A. WATSON ARMOUR, Vice-Pres't.

DIRECTORS
$\$ 909,246.58$

$5,635,000.00$

$11,243,753.6$

$8,103,385.72$

$75,496,202.36$

$13,906,271.23$

$\frac{210,372,491.01}{\$ 314,174,135.89}$

$\frac{210,372,491.01}{\$ 314,174,135.89}$

$\$ 83,404,000.00$

$18,099,209.71$

$\$ 101,503,209.71$

$\$ 103,801,644.88$

$4,645,278.00$

$4,498,416.00$

$6,544,246.58$

$50,000,000.00$

$\$ 100,000,000.00$

$56,126,679.60$

$156,126,679.60$

$\$ 314,174,135.89$

FREDERICK W. CROLL, Treasurer. CHAS. E. HAZARD, Ass't Treas.

GEORGE M. WILLETTS, Secretary.

ALBERT H. WILLETT, Ass't Sec'y.
$33,812,355.42$
J. OGDEN ARMOUR.
CHAS. W. ARMOUR.

A. WATSON ARMOUR. FREDERICK W. CROLL. ROBT. J. DUNHAM.

ARTHUR MEEKER.

SAMUEL MCROBERTS. GEO. B. ROBBINS.

F. EDSON WHITE.

E. A. VALENTINE.

CHAS. J. FAULKNER, Jr., General Counsel. 


\section{PRESIDENT'S REPORT}

T SUBMIT herewith a statement of income for the fiscal year ending October 27, 1917; also 1 of assets and liabilities as of that date.

The net of $\$ 21,293,562.87$ is equivalent to 21 per cent. on our capital stock, and 14.5 per cent. on the average net capital investment.

The usual dividend of 2 per cent. has been declared, payable January 15, 1918, the balance of the year's earnings being reinvested in the business.

We have found it advisable to segregate our foreign interests from our North American interests.

Great expansion - especially in the South American field-made this necessary, and our interests there are now handled by local corporations, which have reinvested the year's earnings in the business.

The gross volume of our business from sources within this country was $\$ 575,000,000$, which figure is $\$ 50,000,000$ greater than our world business in 1916, due largely to abnormal exports to Europe.

The ratio of profit on meat and other food products was 2.21 cents on each dollar of sales.

J. OGDEN ARMOUR.
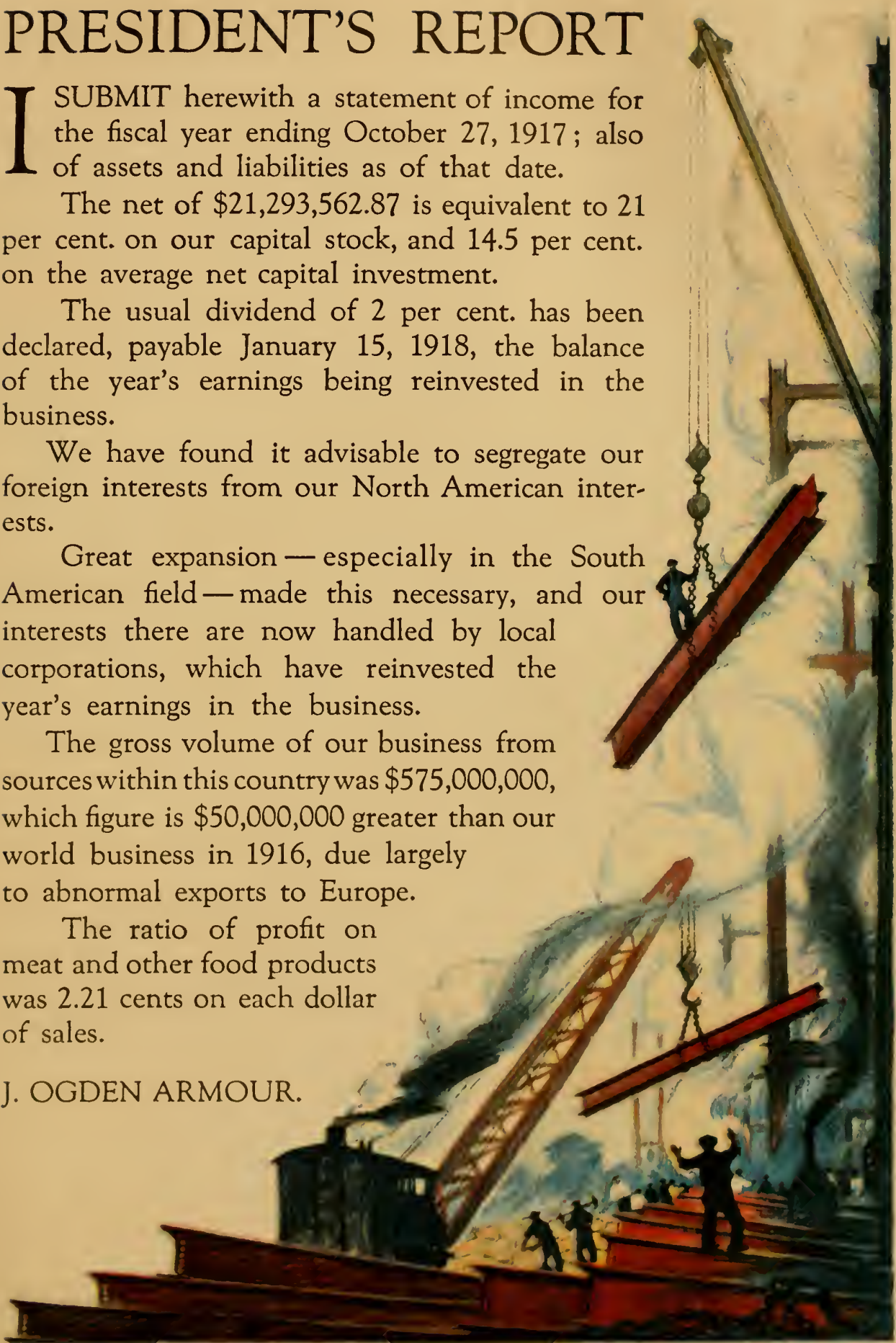


\section{DISTRIBUTION OVER SEASONS AND OVER COUNTRY}

TF production waits on distribution, then it is no less true that distribution is national food insurance for the consumer. Foods not 1 only must be transported throughout the country, but they must be conserved when most bountiful to be redistributed best over seasons of scarcity.

To do this requires a vast and complex system, immense investments in plants, refrigerated warehouses, branch houses, transportation facilities, and a trained organization, under a central directing head, to keep the machinery moving smoothly at every point. It has taken years to perfect these Armour methods. They are today conceded to be as effective as has yet been devised for serving the public. No opportunity to improve will be neglected.

Under the Armour distributive system more than fifty plants, located wherever foods of best quality and quantity are produced, receive and convert the yield of the American producer. Every source of supply is made available. Through over four hundred branch houses, each of which receives from two to forty refrigerated carloads of products per week, deliveries are made by motor truck or wagon in 13,000 cities and towns throughout the country. In addition nearly 4,000 more communities are served by "car route" distribution single cars shipped by way freight, each loaded with products for dealers in ten to fifteen towns. Some three thousand Armour salesmen keep distribution equalized through supplying retailers everywhere.

In the problem of distributing foods over seasons, refrigeration plays the most important part. Cold-storage warehouses assure a supply at reasonable prices to the consumer in times of scarcity and reasonable returns to the producer in times of greatest production, which must be necessary if he is to continue to produce. Cold storage is regulated by natural laws. The most eggs are laid in April and May; the most butter is churned in June and July ; the greatest run of cattle come from the green pastures in October. By storing the surplus a steady supply is made available during the periods of nonproduction.

Despite the popular belief, foods cannot be held indefinitely. The best guarantee of this is that long storage usually means a loss. Storage charges, interest and insurance accumulate, and the goods must be 
moved before the next season's fresh supply comes into market or failure is the result.

Yet, even with a system of distribution perfected over the country and distribution over the seasons brought to a high point of efficiency, the problem of getting perishable foods to the consumer would not be solved, were it not for the refrigerator car. With Armour's development of the refrigerator car, fresh meats and other perishable foods were made available summer and winter alike, and at equalized prices everywhere. It is the connecting link that in itself makes refrigerated storage feasible and the consumer's food supply certain.

Without methods like these the consumer could neither be served with foods in a form that accords with his demands at the time he wants them and at prices within his reach, nor could the channels of distribution be kept open for the producer and a steady market provided every month in the twelve. Similar methods, made nation-wide, would greatly simplify the farmer's problems in many phases. More systematic and better distribution are the imperative needs for the stimulation of greater production on the American farms today.

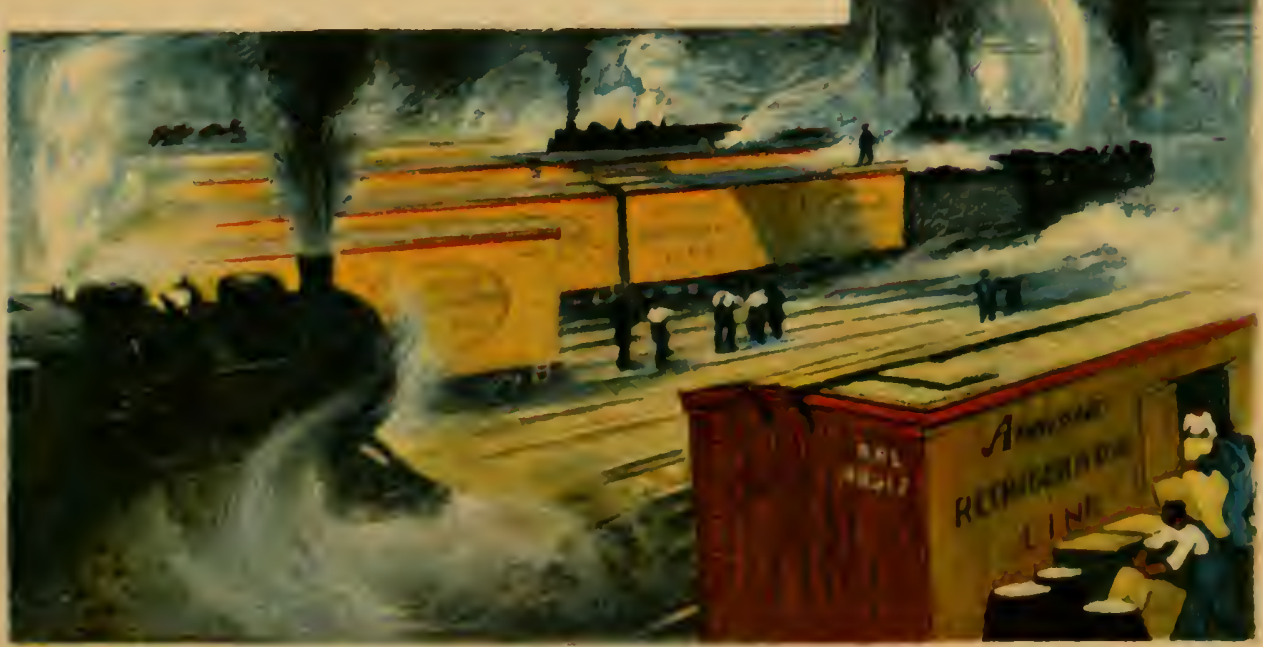




\section{MISUNDERSTANDING}

\section{THROUGH MISINFORMATION}

7 HE packing industry, in common with many big enterprises, has been injured in the public's esteem by the circulation of misin1 formation and misleading part-truths. Confidence of the public is as necessary to big business as it is desirable, and untruthful reports are serious handicaps to the giving of service.

The press, a few months ago, reported the filing of a charge that Armour and Company, together with other concerns, had cornered the California tomato crop. The evidence did not substantiate the charge, and in fact there was nothing to it; yet in the minds of a great many people the charge had force equal to a jury's verdict. For weeks, news of the alleged corner was passed around as though it were a fact instead of a rumor which failed of verification.

Thus does misinformation acquire the influence of truth.

Likewise, part-truths are often the basis for prejudicial rumors. Ill-informed persons, during the past year, publicly claimed that Armour and Company's war profits were so large that they resulted in a stock dividend of 400 per cent. The insinuation of profiteering was wholly without foundation.

The dividend was merely a bookkeeping transaction. During a quarter of a century of growth, Armour and Company had increased the original investment at least five times with earnings that were put back into the business instead of being divided among stockholders. For a period of ten consecutive years there were no dividends, all the earnings having been reinvested in the business.

When reincorporation took place, the capital which was being carried on the books as surplus was transferred to the capital stock account by declaring a stock dividend equal to the amount transferred. Not a penny really changed hands and there was no taint of war profit whatever.

Yet in its misshapen form the story seemed plausible and was accepted by many as truth-to the injury of the good name of Armour.

Armour and Company welcomes investigation and expects it to discredit rumor-mongers and to clear up many of the misunderstandings which have grown up as the result of untruths about the business. 


\section{MERCHANDISING POLICY}

CUGGESTIONS have been made that Armour and Company establish retail stores, presumably in the belief that Armour efficiency would reduce retail costs.

However, such a course is not feasible. For to do so would mean that Armour and Company would have to sell their entire output through their own stores, as obviously they could not hope to act as retailers for part of their products and find customers among retail competitors for the remainder. The tremendous investment involved in establishing stores for such an enormous output as Armour's precludes such a possibility.

Armour and Company will continue to look to the retailer as the final outlet for Armour products. Branch houses are located in chief centers of consumption to give the retailer quick and frequent supplies. A Trade Aid Bureau helps him in better store management and selling; and extensive national advertising of Armour's top-grade products under the identifying Oval Label brand, together with educational work conducted by the Armour Domestic Science Department, creates and develops markets most effectively.

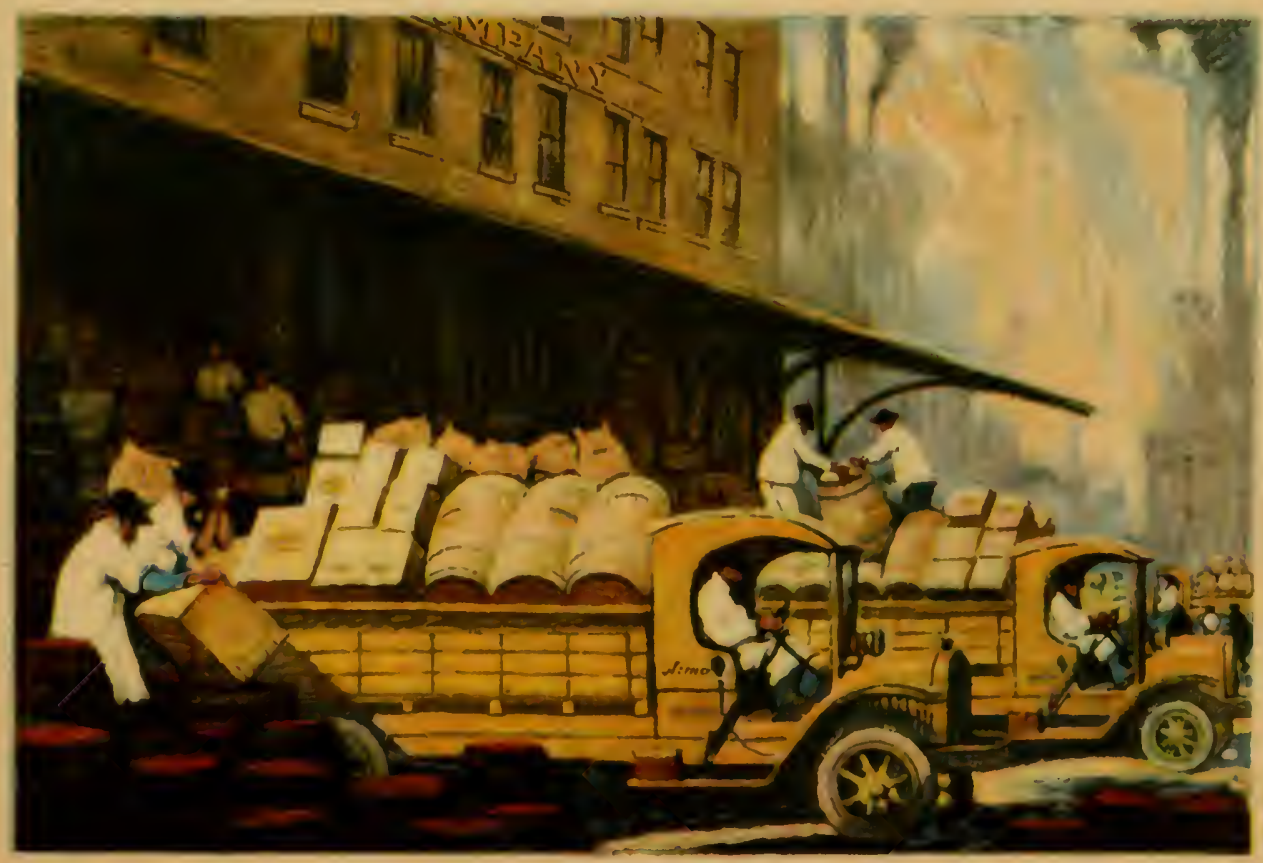




\section{BY-PRODUCTS THAT STABILIZE PRICES}

"7HE ratio of the cost of animals and other materials to the value of the products is greater in the slaughtering and meat-packing 1 industry than is the similar ratio in any other manufacturing lines," is the report of the United States Department of Agriculture in Government Bulletin No. 113. In other words, the livestock producer gets more of the money paid by the consumer than does the producer furnishing supplies to any other industry.

As a matter of fact, the cost of the live animal is generally greater than the price brought by the dressed meat. So that if Armour and Company were forced to pay the producer for his livestock on a meat and hide basis alone, the prices to the grower would have to be much lower or the cost of the meat to the consumer much higher. The reason such conditions do not exist is that high specialization, research and efficiency have developed ways to make commercial use and profit out of every part in or on the animal.

That the producer shares in the returns from the by-products the following figures show: Armour and Company, at the prevailing prices of November, 1917, paid the producer $\$ 170$ for a 1000 -pound steer, the dressed meat of which weighed 600 pounds, which sold to the retailer at $\$ 140.00$. The difference of $\$ 30.00$ was paid to the farmer for the raw materials from which the by-products are manufactured.

Improved processes and refrigeration have made it possible to prepare delectable foods of the edible parts once thrown away, such as sweetbread, tongues, brains, livers and hearts, now prized and served everywhere. Scientific laboratory work has utilized the inedible portions to the last vestige, and today these once worthless parts are made into hundreds of marketable products, from violin strings to soap, from pharmaceutical supplies to glue.

But aside from the savings effected, resulting in better prices to the livestock grower on the one hand and reduced prices for meat to the consumer on the other, the manufacture of these by-products has brought greater efficiency, greater comfort and improved living conditions to the world, and, as in the case of the marvelous medical preparations, the alleviation and often the cure of many subtle and hitherto fatal maladies. 


\section{MAINTAINING QUALITY STANDARDS}

W

ITHOUT the special corps of analytical and experimental chemists constantly at work in the chemical laboratories, which are an adjunct of each of the main Armour meat-packing establishments and fertilizer factories, the present high efficiency, which has become a business by-word in the Armour plants, would be impossible.

The chemical laboratories were installed originally to devise ways of utilizing portions of meat animals which once were discarded as waste. To their success in this field is largely due the scope of the present by-products business.

New responsibilities now rest on the laboratories - they exercise supervision over all raw materials, processes and products. Existing processes are studied, faults remedied and improvements made. New formulas are evolved and made standard at all Armour plants so that the products handled by the company will have the same high quality, whether they come from a plant at Spokane, Wash., at Chicago, or at Jacksonville, Fla.

Everything that is bought or sold must conform to the required Armour specifications. In addition to food supervision the chemical laboratories test and analyze the

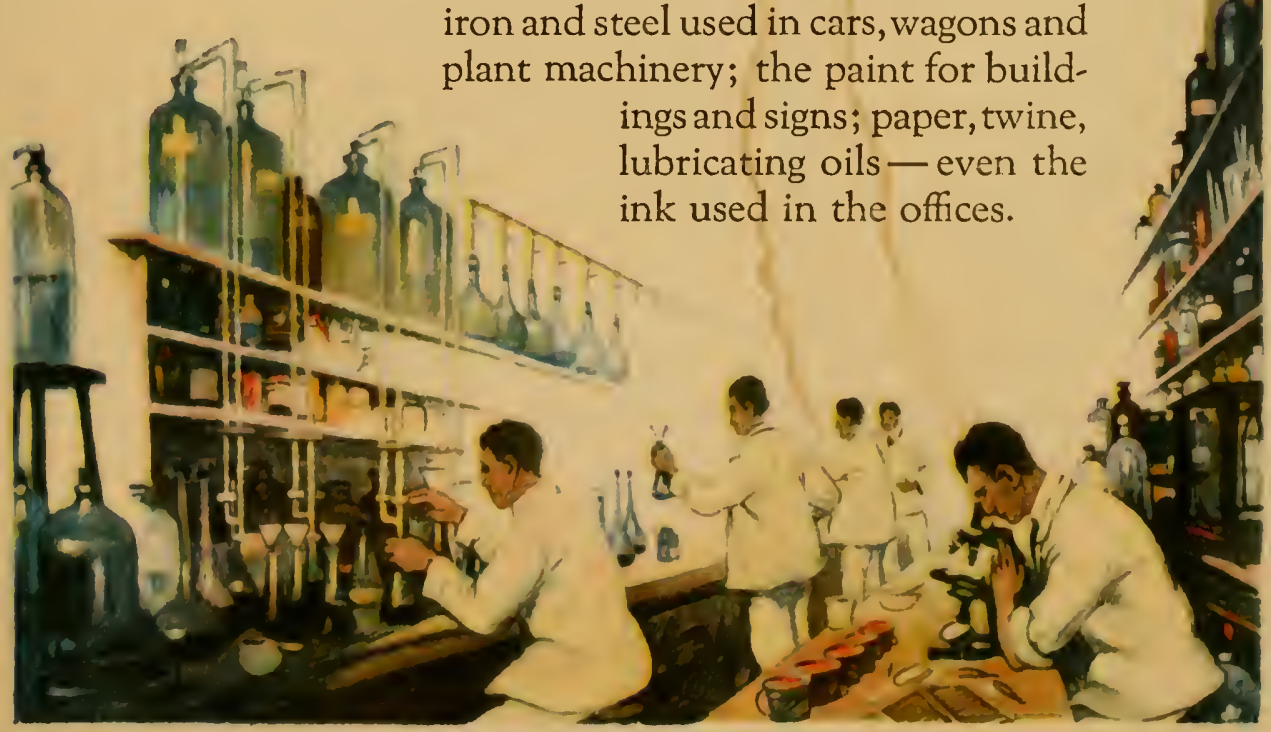




\section{UNDER GOVERNMENT CONTROL}

$\mathrm{B}$ ECAUSE food is a paramount factor in the successful prosecution of the war, the Government has seen fit to assume full and complete control over the industries which purvey foodstuffs. The packing industry is being conducted in accord with directions from the food administration and operated under rules and regulations promulgated by Mr. Herbert C. Hoover, national food administrator, and Mr. J. P. Cotton, chief of the meat division of the food administration.

The most important actions taken by the food administration today have to do with fixing profits of the packers and with organizing and systematizing the machinery for buying and exporting meat to our allies in Europe. All this buying is now done by the food administration.

Packers' profits have been limited to two and a half cents on each dollar's worth of business done, and a further provision applying only to the five largest concerns - including Armour and Company-fixes their total earnings on meat and meat products at not to exceed nine per cent. on investment in that phase of the business.

Armour and Company will endeavor in every way to measure up to the government's requirements and to co-operate fully in its plans.

\section{SOUTH AMERICAN PLANTS}

U

NDER war demands the livestock supply of the embattled countries of Europe has been diminished to an alarming extent. With regard for the need of tremendously increased production for the world, and to relieve the drain on this country, Armour and Company have greatly extended operations in South America. The Armour La Plata plant in Argentine has been doubled in capacity, the plant at Santa Cruz, Patagonia, has been kept in operation, and two new plants have been built in Brazil, a country of boundless opportunities but which, having no outlet, has failed heretofore to realize its fullest opportunities. Under these new incentives South American growers are responding energetically in the work of increasing the world's supply of livestock. 


\section{LABOR'S WELFARE}

70 insure as far as practicable continuity of the operation of our packing plants during the

1 war, we recently agreed, at the instance of the United States Commission on Mediation, to submit all questions arising during that time as to wages and working conditions of our employees to an administrator selected by the Commission for that purpose.

Three motives impel Armour and Company toward an ever-increasing amount of welfare work among employees-desire to improve working conditions, to simplify employment problems, and raise the standard of efficiency.

Armour and Company have not stopped with providing pure drinking water, comfortable locker and dressing rooms, clean and adequate toilets, washrooms and showers, lunch rooms and medical and dental service.

The Armour plan is broader.

A huge gymnasium and swimming pool provide physical exercise and recreation. A camp at a summer resort lake is open to girl and women employees. Bands, glee clubs, dramatic clubs, domestic science clubs and such like are encouraged.

A continuation school will enable office boys to pursue their studies at the expense of the firm.

An innovation in welfare work is the Armour plan of "Hire and Fit" as opposed to the old idea of "Hire and Fire." Discharge is no longer a matter of whim. Each employee is given ample opportunity to find the work for which he is best fitted.

A pension plan, carefully thought out, provides for the future of loyal workers.

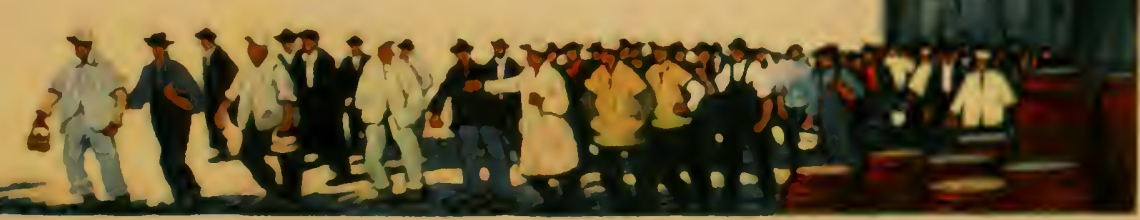




\section{FACTS ABOUT ARMOUR AND COMPANY}

The 57,546 employees of Armour and Company, together with their families, if brought together in one place, would represent a community of 300,000 people, a city larger than Kansas City, Missouri.

Each day 400 refrigerator cars, loaded with Armour food products, are shipped to the 425 Armour branch houses throughout the country.

In the year 1917 Armour and Company paid to the American livestock producer $\$ 93,000,000$ more for cattle, sheep and hogs, than the same poundage would have cost in 1916.

The Armour chilling rooms, in which meat is held for two days to remove animal heat after killing, have a capacity of about $85,000,000$ pounds of meat, and in effect are emptied every other day. Armour cold storages have a capacity of some $35,000,000$ pounds of meat and this tonnage is turned on the average every three months, showing what a relatively small proportion of meat goes into the cold storage.

The supply of meat carried by Armour and Company in cold storages would furnish only a single meal for about one-half of the American public.

The returns from the sale of a steer, as shown by the Government reports, are distributed as follows: "Approximately two-thirds to three-fourths to the stockman, three to four per cent. shipping and stockyards expense, five to six per cent. packing and wholesale distribution, and fifteen to twenty per cent. retailing."

In the preceding pages our purpose has been to present an adequate expression of the motives and functions of the Armour institution, with the hope that a better economic understanding of Armour and Company's operations will result. Sincere suggestions and requests for information about the workings of the Armour organization and methods are welcome at all times.

ARMOUR AND COMPANY.

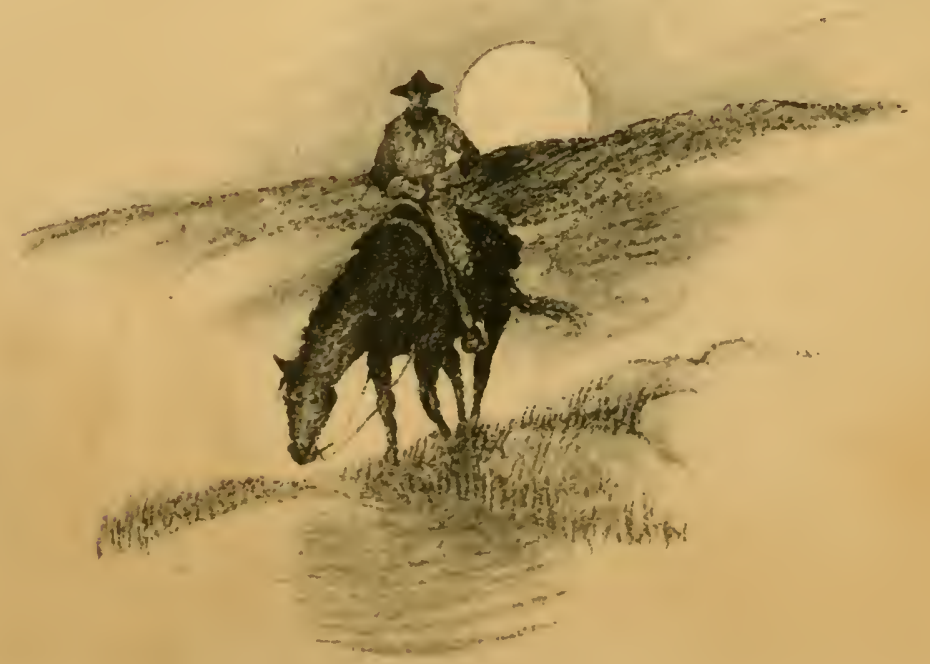




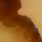

tra

s

Conmen 
